\title{
AVIFAUNA OF AGRO-ECOSYSTEMS OF MAIDAN AREA OF KARNATAKA
}

\author{
S. Basavarajappa
}

Department of Studies in Zoology, Manasagangotri, University of Mysore, Mysore, Karnataka 570006, India

Email: Braj@rediff.com

\begin{abstract}
Diversified wetland agro-ecosystems of Maidan areas of Karnataka have provided congenial habitats for the survival of 27 species of water birds belonging to 13 families. The relative composition of aquatic bird species and their density varied significantly. Further, the Ardeidae members dominated and were common in all habitats. Interestingly, the area was found congenial for certain resident migrants viz., Painted Stork (Mycteria lencepahala), Black Ibis (Pseudibis papillosa) and Oriental White Ibis (Threskiornis melanocephalus), which were recorded every winter. The study showed that, the varied composition of water birds associated with the wetland agro-ecosystem is for sharing common habitat for different purposes. It is hoped that this study would provide a preliminary database for the avifauna of this area, for further research.
\end{abstract}

\section{KEYWORDS}

Agro-ecosystems, aquatic avifauna, Karnataka, Maidan area, relative composition

Birds have fascinated human beings in various ways by their valuable services. They play a vital role in various agroecosystems; their diversity is an indication of congenial habitat for survival (Jayson \& Mathew, 2002). The diversified vegetation of the wetlands of central Karnataka attracts large number of aquatic avifauna. However, in the recent past, the natural wetland patches and bushy scrub areas are depleting (Uttangi, 2001) at a rapid rate due to the expansion of rice fields (Basavarajappa, 2005 a,b). Daniel et al. (1990), Jayson and Mathew (2002) and others have reported on various species of birds in different vegetation types. However, reports on aquatic birds occurring in plains of central Karnataka is not available.

\section{STUdy AREA}

Physiographically, the study area occupies a central position in the state of Karnataka, and lies between $13^{0} 27^{\prime}-14^{0} 39^{\prime} \mathrm{N}$ \& $74^{\circ} 38^{\prime}-76^{\circ} 40^{\prime} \mathrm{E}$ at an altitude of $671 \mathrm{~m}$ (Kamath, 1991). The landscape consists of vast stretches of plains with scattered horticultural gardens, bushy vegetation and irrigated paddy fields. For the present study, the Channagiri taluk of Davangere district was selected. The natural vegetation is typically that of scattered bushy scrub represented by Acacia arabica, A. farmesiana, Mariscus paniceus, Eupatorium indica, Parthenum hysterophorus, Saccharum spontaneum, Ipomoea reptans, Lantana camara and stray trees like Eucalyptus citriodora, E. tereticorms, Pheonx vulgaris, Pongamia pinnata, Mangifera indica, Tamarindus indica and Cocos nucifera and other flora (Basavarajappa, 1998, 2002, 2005a; Kamath, 1991). Three different sites were selected at random covering an area of 1900ha. They were: (i) Kenghalu dominated with rice fields; (ii) Doddathota - with wet grassland, flooded inland with grass and uncultivable grazing pasture located at the margins of sparsely distributed rice fields on the banks of Sulekere, a small seasonal canal; and (iii) Neeravari an area thickly distributed with grassy marshes. The study sites were differently located at $5 \mathrm{~km}$ each. In each site, observations were made fortnightly during 2002-03.

\section{Methodology}

The Variable Width Line Transect Method described by Burnham et al. (1980) was adopted. The transect covered $2 \mathrm{~km}$ in all the three sites for the enumeration of water birds. Altogether, 72 line transects were laid and birds were observed using a binocular (10x30) and identified with the help of field guides (Ali, 1996; Ali \& Ripley, 1983, 1987; Sonobe \& Usui, 1993; Woodcock, 1980). The flora of natural vegetation was identified as per Gambel (1967). The following formula was used for calculating Relative Dominance.

Relative Dominance $=$ ni X 100/N; where, $n i=$ number of individuals of the species; $\mathrm{N}=$ the total number of individuals of all the species seen during the study period. To find out the diversity of birds the commonness index method of Jayson and Mathew (2002) was used. The Commonness Index is the average frequency of sighting of a species in one sampling at a site. Further, Percent Occurrence and Relative Abundance was calculated as follows.

No. of species of each family

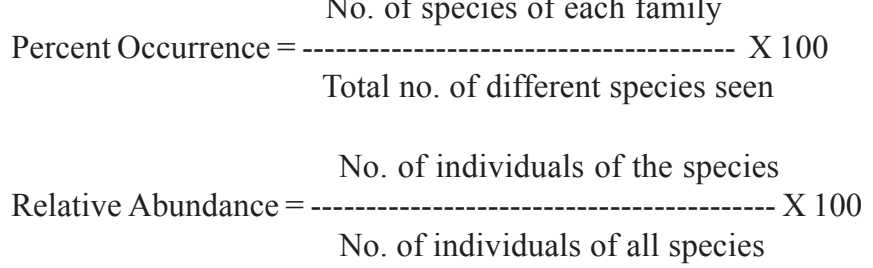

To determine the significant differences of water birds and relative composition of different families, the Kruskal Wallis One Way Analysis of Variance and the Friedman Two-Way Analysis of Variance tests were used as per Saha (1992).

\section{Results AND Discussion}

Details such as family, relative dominance and status of aquatic avifauna in the study area is as given in Table 1. Twenty-seven species of water birds belonging to 13 families were recorded. Of all, family Ardeidae (9 species) was relatively dominant $(68.7 \%)$. It represented $33.4 \%$ of the total number of water bird species surviving under wetland conditions of central part of Karnataka. The most common and abundant species of Ardeidae family were the Cattle Egret (Bubulcus ibis) and Little Egret (Egretta garzetta) followed by Indian Pond Heron or 
Paddy bird (Ardeola grayii), Little Grebe (Tachybaptus ruficollis), Purple Moorehen (Porphyrio porphyrio) (Table 1). Interestingly, the density of water birds varied significantly $\left(\mathrm{X}^{2}\right.$ $=15.60, \mathrm{P}>0.05)$ in different wetland agro-ecosystems of central Karnataka.

Six species of birds namely, Grey Heron (Ardea cinerea), Indian Shag (Phalacrocorax fuscicollis), Crab Plower (Dromas ardeola), Black-winged Stilt (Himantopus himantopus), Pied Avocet (Recurvirostra avosetta) and Common Ringed Plover (Charadrius hiaticula) were uncommon (Table 1), while the Indian Darter (Anhinga melanogaster), Great Cormorant (Phalacrocorax carbo), Sociable Lapwing (Vanellus gregarius), Stone Curlew (Burhinus oedicnemus) and River Tern (Sterna aurantia) were rarely seen in this area. Thus, the relative composition of aquatic birds belonging to different families varied significantly $\left(\mathrm{X}^{2}=22.11, \mathrm{P}>0.05\right)$. Habitats with varied vegetation influence the diversity of bird species (Jayson \& Mathew, 2002). It is presumed that the native flora (i.e., scattered horticultural gardens, bushy scrub and stray trees in the paddy fields) might have extended comfortable shelter and foraging grounds for water birds. As these bird species are heterogeneous in their feeding habit (Ali \& Ripley, 1983, 1987), the available fauna, viz., crabs, snails, calms, worms, insect larvae and pupae in the paddy fields and in water bodies may constitute their feed. Wetlands are potential sources for plankton life. They play an important role in the cycle of changes (i.e., elements of organic matter eaten by bacteria and protozoa and in turn consumed by the insect larvae, rotifers and crustaceans), which form the basis of food for water birds (Uttangi, 2001). By feeding on insect pests, their larvae and pupae, water birds control large amount of pest population in paddy fields. Further, they provide manure. Hence, the ecological role played by water birds in agro-ecosystems of Maidan area is unique of its kind.

The resident migrant (i.e., birds that breed in one part of the area in one season and move to other parts within the state or country in a different season) birds such as Painted Stork (Mycteria leucocephala), Black Ibis (Pseudibis papillosa) and Oriental White Ibis (Threskiornis melanocephalus) were winter migrants in this region. The breeding activities of Black Ibis and Oriental White Ibis were observed at different localities in the wetlands. The area is enriched by small water canals, streams, water bodies (Basavarajappa, 2005b) and sparsely distributed tall stray trees viz., Cocos nucifera, Mangifera indica, Pheonx vulgaris, Tamarindus indica, Eucalyptus citriodora and E. tereticorms. The bushy scrub constituted by Lantana camara, Saccharum spontaneum, Ipomoea reptans and others in the vicinity of paddy fields might have attracted the Oriental White Ibis and Black Ibis. Moreover, they get good food i.e., insects, crabs, insect larvae, pupae and small fishes from this ecosystem. Perhaps, all these conditions might have influenced these resident migrants to breed. To support this, few nests of the Black Ibis and Oriental White Ibis were seen on a few stray coconut trees near paddy fields. Thus, the wetland agro-ecosystems have provided suitable habitats for the survival of these birds. However, in the recent years, the uncultivable grazing fields, bushy scrub areas and wetland patches have been cleared (Uttangi, 2001) and the stray trees removed for paddy cultivation (Basavarajappa, 1998, 2004). Weedicides and insecticides are ruthlessly used in paddy fields to control weeds and insect pests. Many birds associated with wetlands are forced to leave the habitat as villagers cut the emergent vegetation and the number of nests have declined in this area (Basavarajappa, 2002 and 2005a,b). The reason for decline of nests of other birds in general and water birds in particular is not known. This requires thorough scientific monitoring and documentation. Therefore, the preservation of wetland patches is essential to restore water birds.

\section{Conclusion}

The present study emphasizes the need to conduct a detailed study on the status of wetland ecosystems, and biology of water birds to have accurate information on the ecological role of birds associated with wetlands. The agro-ecosystems of Karnataka are diversified with various aquatic birds and 27 species of wetland-associated birds survive in this area. However, in the recent past, the wetland agro-ecosystems in this area are degraded or destroyed due to encroachment for the expansion of rice fields. This would eventually alter the natural vegetation on the banks of water canals, streams and in the uncultivable wetland patches making it unsuitable for birds to roost and nest. Unaltered natural patchy vegetation is essential in agro-ecosystems, which makes it very important to take steps to preserve wetlands flora and avifauna for the health of biodiversity of Maidan areas.

\section{REFERENCES}

Ali, S. (1996) The Book of India Birds. BNHS, Oxford University Press, Bombay.

Ali, S. and S.D. Ripley (1983). Handbook of the Birds of India and Pakistan. Oxford University Press, Oxford.

Ali, S. and S.D. Ripley (1987). Compact Handbook of the Birds of India, Pakistan, together with those of Bangladesh, Nepal, Bhutan and Sri Lanka. Oxford University Press, New Delhi.

Basavarajappa, S. (1998) Status of natural colonies of Apis dorsata in Maidan region of Karnataka, India. Indian Bee Journal 60(3): 1-4.

Basavarajappa, S. (2002). A preliminary report on the Indian Crested Peafowl in Channagiri area, Karnataka. Newsletter for Birdwatchers 42(2): 20-21.

Basavarajappa, S. (2004). Status of the Asian Giant Honey bee Apis dorsata, F. and its conservation in southern part of the Deccan Peninsula, Karnataka, India. In: Gupta, V.K. (Ed.) Prospectives in Animal Ecology and Reproduction. Vol.II. Daya Publishing House, New Delhi.

Basavarajappa, S. (In press a). Habitatic features, relative abundance, sex-ratio and population decline of Pavo cristatus in Channagiri area of Karnataka, India. In: Gupta, V.K. (Ed.) Prospectives in Animal Ecology and Reproduction. Vol. III. Daya Publishing House, New Delhi.

Basavarajappa, S. (In press b). Indian Peafowl Pavo cristatus in the agri-horticultural ecosystems of Maidan area of Karnataka, India. Tiger Paper.

Burnham, K.P., D.R. Anderson and J.L. Laake (1980). Estimation of density from line transect sampling of biological populations. Wildlife Monograph 72.

Daniels, R.J.R., M. Hegde and M. Gadgil (1990). Birds of the manmade ecosystems: the plantations. Proceedings of the Indian Academic Science, Animal Science 99(1): 79-89.

Gambel, J.S. (1967). Flora of the Presidency of Madras. ( $2^{\text {nd }}$ Edn). Vol. I \& II. Botanical Survey of India, Calcutta.

Jayson, E.A. and D.N. Mathew (2002). Structure and composition of 
Table 1. Aquatic avifauna found in the agro-ecosystems of Maidan area of Karnataka

\begin{tabular}{|c|c|c|c|c|c|}
\hline & Family & Common Name & Scientific Name & $\begin{array}{l}\text { Relative } \\
\text { abundance }\end{array}$ & Status \\
\hline 1. & Ardeidae & Indian Pond Heron & Ardeola grayii & 1.10 & $\mathrm{C}$ \\
\hline 2. & Ardeidae & Giant Heron & Ardea goliath & 0.84 & $\mathrm{C}$ \\
\hline 3. & Ardeidae & Black-crowned Night Heron & Nycticorax nycticorax & 0.90 & $\mathrm{C}$ \\
\hline 4. & Ardeidae & Little Egret & Egretta garzetta & 8.29 & VC \\
\hline 5. & Ardeidae & Cattle Egret & Bubulcus ibis & 8.42 & VC \\
\hline 6. & Ardeidae & Large Egret & Ardea alba & 0.45 & C \\
\hline 7. & Ardeidae & Little Green Heron & Egretta picata & 0.97 & $\mathrm{C}$ \\
\hline 8. & Ardeidae & Grey Heron & Ardea cinerea & 0.77 & UC \\
\hline 9. & Ardeidae & Purple Heron & Ardea purpurea & 0.90 & C \\
\hline 10. & Anhingidae & Indian Darter & Anhinga melanogaster & 0.25 & $\mathrm{R}$ \\
\hline 11. & Phalacrocoracidae & Great Cormorant & Phalacrocorax carbo & 0.51 & $\mathrm{R}$ \\
\hline 12. & Phalacrocoracidae & Indian Shag & Phalacrocorax fuscicollis & 0.64 & UC \\
\hline 13. & Podicipedidae & Little Grebe & Tachybaptus ruficollis & 1.29 & C \\
\hline 14. & Ciconiidae & Painted Stork & Mycteria leucocephala & 0.12 & $\mathrm{RM}$ \\
\hline 15. & Threskionithidae & Black Ibis & Pseudibis papillosa & 1.68 & RM \\
\hline 16. & Threskionithidae & Oriental White Ibis & Threskiornis melanocephalus & 1.29 & RM \\
\hline 17. & Rallidae & Purple Moorehen & Porphyrio porphyrio & 1.16 & C \\
\hline 18. & Rallidae & Common Moorehen & Gallinula chloropus & 0.90 & $\mathrm{C}$ \\
\hline 19. & Dromadidae & Crab Plover & Dromas ardeola & 0.58 & UC \\
\hline 20. & Recurvirostridae & Black-winged Stilt & Himantopus himantopus & 0.32 & UC \\
\hline 21. & Recurvirostridae & Pied Avocet & Recurvirostra avosetta & 0.12 & UC \\
\hline 22. & Charadriidae & Sociable Lapwing & Vanellus gregarius & 0.19 & $\mathrm{R}$ \\
\hline 23. & Charadriidae & Red-Wattled Lapwing & Vanellus indicus & 0.45 & $\mathrm{C}$ \\
\hline 24. & Charadriidae & Common Ringed Plover & Charadrius indicus & 0.25 & UC \\
\hline 25. & Scolopacidae & Stone Curlew & Burhinus oedicnemus & 0.12 & $\mathrm{R}$ \\
\hline 26. & Laridae & River Tern & Sterna aurantia & 0.12 & $\mathrm{R}$ \\
\hline 27. & Jacanidae & Pheasant-tailed Jacana & Hydrophasianus chirurgus & 0.32 & C \\
\hline
\end{tabular}

C - Common; VC - Very Common; UC - Uncommon; R - Rare; RM - Resident Migrant

Table 2. Aquatic avifauna representation in families

\begin{tabular}{lllll}
\hline S. No & Family & $\begin{array}{l}\text { Percent } \\
\text { Occurrence }\end{array}$ & $\begin{array}{l}\text { Relative } \\
\text { Abundance }\end{array}$ & Status \\
\hline 1. & Ardeidae & 33.4 & 68.69 & VC \\
2. & Anhingidae & 3.7 & 0.77 & $\mathrm{R}$ \\
3. & Cioconiidae & 3.7 & 3.88 & VR \\
4. & Charadriidae & 11.1 & 2.72 & $\mathrm{R}$ \\
5. & Dromadidae & 3.7 & 1.74 & UC \\
6. & Jacanidae & 3.7 & 0.97 & $\mathrm{C}$ \\
7. & Lariidae & 3.7 & 0.38 & $\mathrm{R}$ \\
8. & Phalacrocoracidae & 7.4 & 3.49 & $\mathrm{UC}$ \\
9. & Podicipediae & 3.7 & 3.88 & $\mathrm{C}$ \\
10. & Rallidae & 7.4 & 8.94 & $\mathrm{UC}$ \\
11. & Recurvirostridae & 7.4 & 1.36 & $\mathrm{C}$ \\
12. & Scolopacidae & 3.7 & 0.38 & $\mathrm{R}$ \\
13. & Threskiornithidae & 7.4 & 0.38 & $\mathrm{RM}$ \\
\hline
\end{tabular}

Each value is a mean of 72 observations.

VC - Very Common; R - Rare; VR - Very Rare; UC - Uncommon;

C - Common; RM - Resident Migrant.

two bird communities in the southern Western Ghats. Journal of the Bombay Natural History Society 99(1):8-25.

Kamath, U.S. (1991). Shimoga District Gazetteer, Karnataka.

Philips, J. (1959). Succession, development, the climax and complex organisms. An analysis of concepts. Part 1 \& 2. Journal of Ecology 22: 559-571.

Saha, T.K. (1992). Biostatistics in Theory and Practice. Emkay Publications, Delhi.

Sonobe, K. and S. Usui (1993). A Field Guide to the Water Birds of Asia. Wild Bird Society of Japan, Tokyo.

Uttangi, J.C. (2001). Conservation and Management Strategy for the Water Fowls of Minor Irrigation Tank Habitats and their Importance as Stopover Sites in Dharwad District. In: Hosetti, B.B. and M. Venkateshwarlu (EDs.). Trends in Wildlife Biodiversity Conservation and Management. Daya Publishing House, Delhi.

Woodcock, M. (1980). Collins Hand Guide to the Birds of the Indian Sub-continent. St. James Palace, London.

\section{ACKNOWLedgements}

I am grateful to Prof. P.R. Naik, the Chairman, DOS in Zoology, University of Mysore, Mysore, for encouragement. I am thankful to Prof. V. Vasudev, and Dr. B.B. Hosetti for their co-operation during my stay at the Department of Applied Zoology, Kuvempu University, Shankaraghatta. Thanks are also due to my childhood friends, who are in Belalagere, for their help during the field study.

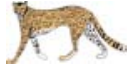

